\title{
MODEL PEMBELAJARAN BERBASIS MASALAH, PENGGUNAAN MEDIA AUDIO VISUAL, DAN VARIASI MENGAJAR GURU TERHADAP HASIL BELAJAR IPS TERPADU
}

\author{
Sebastian Galileo \\ e-mail: Sebastian.galileo54@gmail.com \\ Lilik Sri Hariani \\ e-mail: liliksrihariani@unikama.ac.id \\ Naim \\ e-mail: kornanaim68@yahoo.com
}

(Program Studi Pendidikan Ekonomi, Fakultas Ekonomika dan Bisnis, Universitas Kanjuruhan, Malang)

\begin{abstract}
This study aims to determine how much influence these three factors partially and simultaneously on student learning outcomes. This research was conducted at the junior high school of Pakisaji noble mind. The research population was all VIII grade students, totaling 131 students. This sample of study included 67 students, the sampling method was random sampling. Based on the results of the $F$ test it was found that there was a significant simultaneous effect between the independent variables (problem based learning models, the use of audi visual media and variations of teacher teaching) to the dependent variable (learning outcomes). The results of this $t$-test show that the use of problem-based learning models on learning outcomes has a significant effect, the use of audio-visual learning media on learning outcomes has a significant effect, and variations in teacher teaching on learning outcomes have a significant effect. Based on the results of this research it is expected that in an effort to improve student learning outcomes, teachers should be able to apply the right model in KBM, use learning media according to students' needs, and apply the variety of teaching when delivering learning material.
\end{abstract}

Keywords : Problem Based Learning, audio visual, variations, learning outcomes

\begin{abstract}
Abstrak: Penelitian ini bertujuan untuk mengetahui seberapa besar pengarauh ketiga faktor tersebut secara parsial dan simultan terhadap hasil belajar siswa. Penelitian ini dilaksanakan pada lembga smp budi mulia pakisaji. Populasi penlitian ini adalah seluruh siswa kelas VIII yang berjumlah 131 siswa. Sampel penilitaian ini berjumblah 67 siswa, metode pengambilan sampel dengan cara random sampling. Berdasarkan hasil uji $F$ ditemukan bahwa terdapat pengaruh yang signifikan secara simultan antara variabel bebas (model pembelajarn berbasis masalah, penggunaan media audi visual dan variasi mengajar guru) terhadap variabel terikat ( hasil belajar). Hasil uji t penilitian ini menunjukan hasil bahwa penggunaan model pembelajaran berbasis masalah terhadap hasil belajar berpengaruh siginfikan, penggunaan media pembelajaran audio visual terhadap hasil belajar berpengaruh signifikan, dan variasi mengajar guru terhadap hasil belajar berpengaruh secara signifikan. Berdasarkan hasil penilitian ini diharpkan dalam upaya peingkatan hasil belajar siswa hendaknya dalam KBM guru mampu menerpakan model yang tepat, menggunakan media pembelajaran sesui kebutuhan siswa, dan menerapkan adanya variasi mengajar pada saat menyampaikan materi pembelajaran.
\end{abstract}

Kata kunci : Problem Based Learning, audio visual, variasi, hasil belajar 


\section{PENDAHULUAN}

Hasil belajar dipengaruhi beberapa faktor, salah satu faktor yang diduga mempengaruhiu yaitu model pembelajaran. Guru sebagai fasilitator harus memeliki kemampuan untuk memeilih model pembelajaran yang efektif untuk meningkatkan kemampuan berfikir siswa. Dengan inovasi model pembelajaran diharapkan akan tercipta suasana belajar aktif dan siswa maudah menguasai dan memehami materi pembelajaran. Salah satu model pembelajaran yang memberdayakan siswa adalah model pembelajaran problem based learning (PBL). Amir, (2009) menjelaskan "model pembelajaran berbasis masalah merupakan model yang menantang siswa bekerja sama dalam kelompok mencari solusi dari masalah dengan mengkaitkan rasa keingintahuan serta analisis siswa untuk berfikir kritis dan analitis". Penggunaan model pembelajaran berbasis, diharapkan siswa dalam pembelajaran lebih efektif, lebih aktif dan mampu menerima pelajaran dalam memahami materi. Pembelajaran berdasarkan masalah digunakan untuk merangsang berfikir tingkat tinggi dalam situasi berorientasi masalah, termasuk di dalamnya belajar bagaimana belajar (kusnandar, 2009).

Hasil penilitaian Paembonan (2015), rata-rata hasil belajar siswa yang diajarkan dengan model problem based learning (PBL) lebih tinggi dari pada hasil belajar siswa dengan mengguanakan model konvensional, sedangkan penelitian Matthew (2011), menunjukan bahwa PBL merupakan strategi pembelajaran yang bermanfaat dan menyengkan. PBL juga menempatkan siswa sebagai pusat dari proses belajar yang akan meningkatkan pengetahuan, keterampilan dan pemahaman. Dari penjelasan para ahli di atas dan temuan hasil penilitian tentang penggunaan PBL, dapat disimpulkan bahwa model pembelajarn problem based learning mampu meningkatkan hasil belajar siswa.

Faktor kedua yang diduga mempengaruhi hasil belajar siswa dalah pengguan media pembaljaran yang menarik sehingga mampu menciptakan suasana belajar yang menyengkan. Heinich dalam Rusman (2011:169) mengatakan, "media merupakan alat saluran komunikasi. Media berasal dari bahasa Latin dan merupakan bentuk jamak dari kata medium yang secara harfiah berarti perantara yaitu perantara sumber pesan (a source) dengan penerima pesan (a receiver)". Oleh karena itu media dalam proses pembelajarn sangatlah penting, karena melalui media, materi pembelajaran dapat dismapikan kepada siswa, sehingga siswa mampu memehami materi pembelajaran. Salah satu media pemblajaran yang mamapu menciptakan susana belajar yang mengajak siswa berperan aktif dan menyengkan adalah media audio visual. Menurut Wina Sanjaya (2011) dalam bukunya mendefinisikan bahwa "media audio merupakan media atau bahan yang mengandung pesan dalam bentuk auditif/pita suara atau piringan suara yang dapat merangsang pikiran dan perasaan pendengar sehingga terjadi proses belajar". Sedangkan menurut Yhudi Munandi (2008) media audio visual adalah" suatu media pengabung dari audio visual yang diterima dengan mengguanakan panca idra". Hasil penelitian yang dilakukan oleh Siti Akmaliah (2014) menjelaskan bahwa terdapat pengaruh yang signifikan antar media audio vidual terhadap hasil belajar siwa pada materi kebutuhan manusia.

Variasi mengajar guru juga diduga dapat memepengaruhi hasil belajar siswa. Peran guru juga sangatlah penting dalam menunjang keberhasilan belajar siswa karena siswalah yang akan merasakan hasil setelah guru mengajar. Menurut Mulyasa (2008:78) variasi dalam pembelajaran adalah "perubahan dalam proses kegiatan yang bertujuan untuk meningkatkan motivasi belajar 
peserta didik, serta mengurangi kejenuhan dan kebosanan". Dari pengertian tadi jelaslah bahwa guru perlu melakukan variasi dalam mengajar agar siswa tidak bosan, perhatian siswa tidak berkurang, siswa tidak mengantuk dan siswa mendapatkan hasil belajar yang baik. Sebaliknya jika seorang guru tidak dapat menggunakan variasi dengan baik, maka siswapun tidak akan bersemangat dan suasana belajar akan membosankan. Oleh karena itu, guru merupakan salah satu faktor yang penting terhadap hasil belajar siswa. Untuk itu maka penulis berinisiatif meneliti faktor-faktor penyebab rendahnya hasil belajar siswa di SMP Budi Mulia Pakisaji. Rendahnya hasil belajra IPS di SMP Budi Mulia Pakisaji dilihat dari nilai raport semester genap tahun ajaran 2016/2017 yang lalu.

\section{TINJAUAN PUSTAKA}

\section{Hasil Belajar}

Hasil belajar merupakan dasar yang digunakan untuk menentukan tingkat keberhasilan siswa dalam memahami suatu pelajaran. Dalam proses belajar mengajar agar hasil belajar siswa meningkat harus terjadi interaksi antara guru dan siswa sehingga terjadi suatu perubahan tingkah laku dalam individu (siswa). Hasil belajar menurut Susanto (2013:5) yaitu, "perubahan-perubahan yang terjadi pada diri siswa, baik yang menyangkut aspek kognitif, afektif, dan psikomotor sebagai hasil dari kegiatan belajar. Hasil belajar yang dicapai oleh peserta didik merupakan hasil interaksi antara berbagai faktor yang mempengaruhi baik faktor internal (bersumber dari dalam diri peserta didik),maupun faktor eksternal (berasal dari luar diri peserta didik)".

\section{Pembelajaran Berbasis Masalah}

Sani (2014: 127) menyatakan bahwa "pembelajaran berbasis masalah merupakan pembelajaran yang penyampaiannya dilakaukan dengan cara menyajikan suatu permasalahan, mengajukan pertanyaan-pertanyaan, mempasilitasi penyelidikan, dan membuka dialog permasalahan yang dikaji hendaknya merupakan permasalahan kontekastual yang ditemukan peserta didik dalam kehidupan sehari-hari". Bern \& erickson dalam komalasari (2011: 59) menyatakan bahwa "pembelajaran berbasisi masalah merupakan strategi pembelajaran yang melibatkan siswa dalam memcahkan masalah dengan mengintegrasikan berbagai konsep dan ketrampilan dari berbagai disiplin ilmu. Strategi ini meliputi pengumpulan dan menyatukan informasi, dan memperesentasikan penemuan".

\section{Media Audio Visual}

Levie dan Lanz dalam Azhar Arsyad (2013:34) mengemukakan empat fungsi media pengajaran yaitu : 1) Fungsi Atensi, di sini media audio visual merupakan inti, yaitu menarik dan mengarahkan perhatian siswa untuk berkonsentrasi, 2) Fungsi afektif, media visual dapat terlihat dari tingkat kenikmatan siswa ketika belajar atau membaca teks yang bergambar, 3) Fungsi kognitif,media visual terlihat dari temuan-temuan penelitian yang mengungkapkan bahwa lambang visual atau gambar memperlancar pencapaian tujuan untuk memahami dan mengingat informasi atau pesan yang terkandung dalam gambar, 4) Fungsi kompentaris,media pengajaran terlihat dari hasil penelitian bahwa media visual yang memberikan konteks untuk memahami teks membantu siswa yang lemah untuk membaca juga mengorganisasikan informasi dalam teks dan mengingatnya kembali dengan kata lain

\section{Variasi Belajar}

Variasi diartikan sebagai perbuatan guru dalam konteks proses belajar mengajar yang bertujuan mengatasi kebosanan siswa, sehingga dalam proses belajarnya siswa senantiasa menunjukkan 
ketekunan, keantusiasan, dan berperan serta secara aktif. (Hasibuan, 2008:64) Menurut Mulyasa (2008:78) variasi dalam pembelajaran adalah "perubahan dalam proses kegiatan yang bertujuan untuk meningkatkan motivasi belajar peserta didik, serta mengurangi kejenuhan dan kebosanan"

\section{METODE}

Jenis penelitian ini adalah jenis penelitian eksplanasi (explanatory research). Penelitian eksplanasi berfungsi untuk menguji hubungan antara variabel yang dihopotesis. Penelitian dengan metode penelitian kuantitatif akan dilaksanakan di SMP Budi Mulia pakisaji pada siswa kelas VIII yang terdiri dari empat kelas yaitu kelas VIII A, VIII B, VIII C, dan VIII D untuk prestasi belajar yaitu data dokumentasi nilai rata-rata ulangan semester genap tahun ajaran 2016/2017 dan nilai rata-rata nilai ulangan tengah semester ganjil tahun ajaran 2017/201 mata pelajaran IPS Terpadu. Penelitian ini menggunakan analisis deskriptif dan analisis regresi linier berganda. Dalam penelitian ini populasinya adalah siswa-siswi kelas VIII SMP Budi Mulia Pakisaji yang jumlah keseluruhannya adalah 130 siswa.

Teknik pengumpulan sampel dalam penelitian ini dilakukan menggunakan metode teknik acak sederhana (simple random sampling). Dari teori Arikunto maka peneliti mengambil sampel 50\% dari jumlah populasi. Sampel penelitian ini adalah siswa kelas VIII A yang berjumlah 18 siswa/siswi, kelas VIII B yang berjumblah 15 siswa/siswi, kelas VIII C yang berjumblah 15 siswa/siswi dan kelas VIII D yang berjumblah 17siswa siswi.

\section{PEMBAHASAN}

Pembelajaran berbasis masalah adalah konsep belajar yang mengkaitkan materi pelajaran dengan situasi dunia nyata siswa dan mendorong siswa membuat hubungan antara pengetahuan yang dimilikinya dengan penerapannya dalam kehidupan mereka sebagai anggota kelaurga dan masyarakat. Dalam penelitian ini, pembelajaran berbasis masalah berpengaruh secara positif terhadap hasil belajar yaitu sebesar 52,15\%. Pada pembelajaran IPS siswa harus mampu menghubungkan antara ide abstrak IPS dengan situasi dunia nyata yang pernah dialami atau pun yang pernah dipikirkan siswa, karena sesungguhnya mata pelajaran IPS tersebut muncul dari kehidupan nyata. Sebagai contoh, materi masalah sosial pada dasarnya dapat dari penomenapenomena/masalah yang timbul dari masyarakat. Dengan mengetahui mata pelajaran IPS bagian dari kehidupan sehari-hari, maka siswa akan belajar dengan lebih bermakna, mereka tahu tujuan belajar, sehingga pembelajaran IPS lagi membosankan tetapi menyenangkan.

Pembelajaran berbasis masalah juga sangat membantu siswa untuk menjadi lebih dewasa dan semakin matang saat menghadapi persoalan, baik itu persoalan lingkungan, sosial, sekolah maupun persoalan dalam keluarganya, apalagi seperti yang dijelaskan di atas, informasi sudah sangat mudah diakses oleh semua kalangan termasuk siswa itu sendiri baik itu melalui ponsel, warnet, majalah dan lain sebagainya. sehingga berberagam solusi pun sudah banyak disiapkan di laman-laman terkait yang disediakan oleh media social.

Salah satu media pembelajaran yang dapat mendukung proses belajar mengajar adalah media audio visual. Berdasarkan hasil analisis secara statistic media audio visual (X2) berpengaruh secara signifikan terhadap hasil belajar (Y) yaitu sebesar 29,47\%. Media audio visual dapat dibagi menjadi dua jenis. Jenis pertama, dilengkapi fungsi peralatan suara dan gambar dalam satu unit, 
dinamakan media audio visual murni,seperti film gerak (movie) bersuara, televisi dan video. Jenis kedua adalah media audio visual tidak murni yakni apa yang kita kenal dengan slide, opaque, OHP dan peralatan visual lainya bila diberi unsur suara dari rekaman kaset yang dimanfaatkan secara bersamaan dalam satu waktu atau satu proses pembelajaran

Selain itu secara parsial hasil penelitian menunjukkan bahwa terdapat pengaruh yang positif dan signifikan antara variasi mengajar guru (X3) terhadap hasil belajar siswa pada mata pelajaran IPS terpadu (Y) yaitu sebesar 48,47\%.Variasi mengajar guru membuat siswa menemukan suasana baru dalam belajar sehingga tidak bosan, variasi mengajar guru menjadikan siswa semakin tertantang untuk berbuat, dan variasi guru juga membuat sang guru menjadi lebih cerdas, berwawasan luas, dan energik. Selalu ada cara untuk mengatasi permasalahan siswa yang sedang dialami.

Keterampilan menggunakan variasi merupakan salah satu keterampilan mengajar yang dikuasai guru. Dalam proses pembelajaran, tidak jarang rutinitas yang dilakukan guru seperti masuk kelas, mengabsen siswa, menagih pekerjaan rumah, atau memberikan pertanyaan-pertanyaan yang dapat membuat siswa jenih bosan. Subjek didik adalah manusia yang memiliki keterbatasan tingkat konsentrasi sehingga membutuhkan suasana baru yang membuat fresh dan bersemangat untuk melanjutkan kegiatan pembelajaran.

\section{KESIMPULAN}

Berdasarkan hasil penelitian yang telah dilakukan dan dianalisis maka ada beberapa hal yang perlu disimpulkan antara lain: 1) Terdapat pengaruh yang signifikan antara pembelajaran berbasis masalah terhadap hasil belajar siswa kelas VIII di SMP Budimulya Pakisaji Malang, 2) Terdapat pengaruh yang signifikan antara media audio visual terhadap hasil belajar siswa kelas VIII di SMP Budimulya Pakisaji Malang, 3) Terdapat pengaruh yang signifikan antara variasi mengajar guru terhadap hasil belajar siswa kelas VIII di SMP Budimulya Pakisaji Malang, 4) Terdapat pengaruh yang signifikan antara pembelajaran berbasi masalah, media audio visual dan variasi mengajar guru terhadap hasil belajar siswa kelas VIII di SMP Budimulya Pakisaji Malang.

\section{DAFTAR PUSTAKA}

Anasrullah, 2011. Upaya Meningkatkan Minat Belajar Siswa Pada Mata Pelajaran IPS Ekonomi Pada Materi Perekonomian Indonesia Dengan Menggunakan Media Audio Visual di SMPN 13 kota Tangerang Selatan. Jurusan Pendidikan IPS, FITK UIN Syarif Hidayatullah Arsyad, Azhar, 2013. Media Pembelajaran, Jakarta : PT. Raja Grafindo Persada

Amir, M.T. 2009. Inovasi Pendidikan Melalui Problem Based Learning : Bagaimana Pendidik Memberdayakan Pemelajar Di Era Pengetahuan. Jakarta: Kencana Prenada Media Group

Anjani, D. 2014. Pengaruh Problem Based Learning (PBL) Pada Mata Pelajaran IPA Terhadap Kemampuan Berpikir Kritis Siswa Kelas VIII SMP Ta'Mirul Islam Surakarta Semester Genap Tahun Ajaran 2013/2014. Skripsi (tidak diterbitkan). Surakarta: Universitas Muhammadiyah Surakarta.

Aunurrahman. 2009. Belajar dan Pembelajaran. Bandung: Alfabeta.

Asfadi, B., Yelianti, U., \& Budiarti, R.S. 2014. Pengaruh Model Pembelajaran Berbasis Masalah (Problem Based Learning) Terhadap Hasil Belajar Biologi Siswa Kelas X SMA N 3 Kota Jambi. Jambi: Universitas Jambi. 
Akmalia, Siti. 2014. Pengaruh Penggunaan Media Audio Visual Terhadap Hasil Belajar Ekonomi Di Kelas X MA Attaqwa. Jakarta: UIN Syarif Hidayatulah.

Arsyad,Azhar. 2010. Media Pembelajaran. Jakarta: PT Raja Grafindo Persada

Heninich, Molenda, russel. 2011. Instructional media and new technologies of instrucution. englewood cliffs, N.J : prentice-hall

Marno \& Idris 2008. Strategi Dan Metode Pengajaran Menciptakan Keterampilan Mengajar Yang Efektif. Yogyakarta: Ar-ruzz media grup 